\title{
The impact of logistics solutions on customer satisfaction: an exploratory qualitative study of manufacturing companies
}

\author{
Andrea Chiarini - Alex Douglas
}

\begin{abstract}
Purpose of the paper: The main purpose of this paper is to expand the debate concerning the different logistics solutions implemented in order to increase customer satisfaction.

Methodology: This research utilises a multi-case study approach conducted within 12 medium- and large-sized Italian manufacturing companies and the interviews of 16 managers. The interview questions were based on key issues derived from the extant literature.

Findings: Analysing and coding the answers of the managers led to the identification of five theoretical categories of logistics solutions to increase customer satisfaction. Categories such as 'Supplier with innovative logistics knowledge and skills', 'Green logistics solutions' and 'Lean and agile solutions' were deemed the most important with regards to impact on satisfaction, whereas 'Reverse logistics solutions' and 'Sharing ICT and logistics performance measurement system' were considered less important.

Research limitations: The limitations of this research are mainly linked to the use of a small sample of companies and a qualitative inductive inquiry which has led to more exploratory than validated results.

Implications: Based on the reported results, practitioners who want to implement logistics solutions in manufacturing companies can now choose solutions that will best impact customer satisfaction. For academics the challenge is to further validate the theoretical categories that emerged from this research as hypotheses.

Originality/value of the paper: This paper brings to light original and valuable findings related to the priorities of logistics solutions for customer satisfaction showing unexpected results in terms of impact ranking.
\end{abstract}

Key words: logistics solutions; customer satisfaction; manufacturing companies; qualitative research

\section{Introduction}

Over the years customer satisfaction has dramatically changed in terms of the customers' requirements from the suppliers. Customers have gradually moved from a product-dominant logic to a service-dominant logic (Flint $e t$ al., 2011).

In the past customer satisfaction was more focused on requirements such as quality and reliability reducing costs of poor quality (Griffin et al., 1995).

However, the conformance quality of products is just one dimension of customer satisfaction and companies have learnt that customer 
sinergie Vol. 33, N. 97, 2015

requirements are bound to other factors such as shipment, delivery and packaging. In response, over time, companies have down-streamed customer satisfaction requirements through their production and logistics processes including the external supply chain. Management systems and principles related to agile and leanness ${ }^{1}$ have affected more and more production and logistics solutions because of their connections with customer satisfaction (Khurana and Sohal, 2011).

Indeed, customer satisfaction, from a logistic point of view, can be defined as the right product, at the right price, in the right place, in the right condition, at the right quality and at the right time (Lai and Cheng, 2009).

Manufacturing companies which supply to other companies, with no direct relationships with consumers, are affected by similar principles and for them the downstreaming of customer satisfaction to production and logistics processes is also important. For instance, on-time delivery is fundamental for customers and it requires suppliers to reengineer both internal and external logistics processes, including their supply-chain management. Furthermore, other requirements that are sometimes not considered to be as important as the product, such as packaging and transportation, can affect customer satisfaction. Logistics requirements can also have an impact on environmental management and green processes (Sbihi and Eglese, 2010; Genchev et al., 2011).

The aim of this paper is to enlarge the debate concerning the different logistics solutions implemented by manufacturing suppliers to increase customer satisfaction and to determine their impact on it. In particular this research, by means of semi-structured interviews, aims to identify and propose new links between logistics solutions theory and customer satisfaction. The semi-structured interviews involved 12 large Italian manufacturing companies from different sectors. Their 16 supply chain and logistics senior managers were interviewed to identify their understanding of what they believed to be important within their suppliers in order for them to be satisfied customers.

\section{Literature review}

There are many papers concerning customer satisfaction and how companies can improve processes from marketing to shipping in order to increase customer satisfaction. Nowadays it is taken for granted that customer satisfaction has many aspects and is not just linked to the quality of the product (Kristianto et al., 2012; Meybodi, 2015). In particular, it has been ascertained that a logistics dimension is important in customer satisfaction. Lai and Cheng (2009, p. 111), for instance, reported that customer satisfaction is linked:

1 Lean is a production system which enables the reduction of waste and product lead-time. Agile is often used in connection with lean to emphasise the ability of an organisation to respond rapidly to changes in demand in terms of volume and time. 
to the ability to deliver the right amount of right product, at the right place, at the right time, in the right condition with the right information.

For the scope of this paper, only papers concerning logistics solutions for the manufacturing industry and customer satisfaction have been taken into account.

From the 1990s some authors demonstrated a positive relationship between customer satisfaction requirements and delivery performances and logistics solutions (Sharma et al., 1995; Choi and Eboch, 1998; Beamon, 1999; Cermak et al., 2011). Cermak et al. (2011) even discussed the fact that customers can participate in the specification and delivery of the services. In this sense, suppliers have to quickly react to customer's demand increasing their abilities of mastering all the processes including the logistics ones.

Logistics has been described as being important for integrating the internal operations of an organisation with the supply chain processes to increase customer satisfaction. For instance, Bowersox et al. (2002) investigated all the supply management processes which can affect logistics and customer satisfaction and reported that a logistical value proposition and logistics have a big impact on customer satisfaction leveraging on order processing, inventory management, transportation, handling and packaging, as well as facility network design.

Stank et al. (2003) investigated the relationships between customer satisfaction, customer loyalty, market share and logistics service performance. The research did not investigate specific tools or principles relating to the three dimensions.

Zhang et al. (2005) demonstrated by means of a quantitative inquiry carried out in US manufacturing organisations that logistics flexibility is a fundamental requirement for responding to changing customer needs. Flexible competence and flexible capability are critical to customer satisfaction and according to their results they have to be combined. However, in their paper the authors do not intentionally investigate what the main logistics solutions are for improving customer satisfaction.

Lun et al. (2015) analysed and highlighted how flexibility for the supplier is mainly a matter of acquiring the right skills and the organisational capability in order to follow better the evolution of customer's requests.

Bienstock et al. (2008) focused on the use of particular information technology tools which can better link a company's processes with its customers' ones, sharing also outcome performances. According to Bienstock et al. (2008, p. 205):

Information technology can have significant effects on logistics operations, facilitating collaboration among supply chain partners, as well as allowing the automation of many routine logistics activities.

Interestingly, Bienstock et al. (2008) measured customers' perception of logistics quality service performance from their suppliers. This research identified that some logistics issues are important for customer satisfaction. In particular, (Bienstock, 2008, p. 212) were identified the ability to understand customers' business situations, the effectiveness and ease of use 
Sinergie Vol. 33, N. 97, 2015

of product ordering procedures, the availability and accuracy of order information, the ability of suppliers to handle order discrepancies, the availability of products in suppliers' inventories to fulfil orders, the timeliness of product delivery and the condition of products ordered (i.e., in terms of damage).

And in terms of performance, according to Gunasekaran et al. (2004), the measurement of supplier's performance has a relevant effect on the possibility of increasing customer satisfaction. A particular framework of indicators allows suppliers to control and improve performances such as delivery, quality and service in general. Gunasekaran et al. (2004) highlighted the importance of measuring performance in an automatic way by means of ICT solutions. Similar conclusions can be founded also in Gunasekaran et al. (2001), Tracey and Leng Tan (2001) and Khan et al. (2012).

Vona (2011) investigated logistic districts highlighting that to meet more challenging goals, companies have to reinvent their logistic processes and choose the best outsourcers for logistic activities. According to Vona (2011) in order for a company to satisfy its customers better, with particular reference to delivery times, it has to choose the best outsourcers and integrate them into its processes.

Del Baldo (2011) came to similar conclusions dealing with the integration between carriers, information technology firms and manufacturing companies. Apparently perfect control over the entire network makes a difference in terms of the levels of performance achieved.

A particular group of logistics solutions for increasing customer satisfaction deserves specific discussion. These solutions, classified as green $\operatorname{logistics}{ }^{2}$, are related to solutions which take into account environmental and social factors (Murphy et al., 1996; Murphy and Poist, 2000; Dekker et al., 2012; McKinnon et al., 2012; Chiarini, 2014). According to Sbihi and Eglese (2007, p. 99):

Green Logistics activities include measuring the environmental impact of different distribution strategies, reducing the energy usage in logistics activities, reducing waste and managing its treatment.

In this particular group, reverse logistics is considered one of the most important solutions. Reverse logistics concerns companies specifically when products have to be recovered for quality problems as well as when they are at their end-of-life state (Fleischmann et al., 2000; Rogers and Tibben-Lembke, 2001).

In summary, from the literature review it can be claimed that customer satisfaction is positively affected by logistics solutions. The state-of-theart concerning this topic shows how customer satisfaction is mainly affected by six issues. Warehouse and inventory management, including handling and packaging solutions can surely affect customer satisfaction (Sharma et al., 1995; Choi and Eboch, 1998; Beamon, 1999); according to the literature review, fundamentally because they can increase in some

2 Green logistics became a catchword firstly in the transportation industry in the 1980s. It grew out of the growing awareness of environmental problems. 
ways delivery performances and product integrity (Sharma et al., 1995; Vona, 2011). The control and integration of the supply chain into the company's operation is another way of increasing customer satisfaction. Once more, this is due to the possibility of improving delivery performances. Moreover, in terms of control and better managing the product in its different production stages, also ICT processes can contribute. (Gunasekaran et al., 2004; Bienstock et al., 2008). By the same token, according to the literature review, KPIs control and measurement can be considered as an important part of ICT solutions.

Lastly, green logistic solutions have increased customers' attention over time. According to the results of the literature review, through these particular green solutions the supplier can help the customer to better respect the compliance to environmental laws and regulations. Noteworthy how all these issues, once mastered by the supplier, can improve the supplier's skills, increasing customer satisfaction.

However, in the literature, there is a lack of understanding of what these solutions are, in what way and to what degree they interact with customer satisfaction. In particular there is no trace of quantitative inquiries which can demonstrate the relative importance of these issues to customers.

Anyhow, from the literature review some specific theoretical key issues have emerged. Each key issue has been linked with the main literature according to the following list.

$K_{1}$ : customer satisfaction is affected by warehouse and inventory management solutions (Sharma et al., 1995; Beamon, 1999; Bowersox et al., 2002; Sbihi and Eglese, 2010; Genchev et al., 2011)

$K_{2}$ : customer satisfaction is affected by the control and integration of the supply chain into the company's operations (Bowersox et al., 2002; Cermak et al. 2011; Del Baldo, 2011; Vona, 2011)

$K_{3}$ : customer satisfaction is affected by the sharing and managing of common Information Communication Technology (ICT) processes (Gunasekaran et al., 2004; Bienstock et al., 2008)

$K_{4}$ : customer satisfaction is affected by the sharing and managing of common key performance indicators (KPIs) and performance data (Gunasekaran et al., 2001; Tracey and Leng Tan, 2001; Gunasekaran et al., 2004; Khan et al., 2012)

$K_{5}$ : customer satisfaction is affected by the mastery of knowledge and skills linked to logistics from the supplier (Zhang et al., 2005; Cermak et al. 2011; Lun et al., 2015)

$K_{6}$ : customer satisfaction is affected by the green logistics solutions adopted by the supplier (Fleischmann et al., 2000; Rogers and TibbenLembke, 2001; Sbihi and Eglese, 2007) 
sinergie Vol. 33, N. 97, 2015
These key issues have been transformed into eight open questions for the design of the semi-structured interview guide described in the following section.

\section{Methodology}

This research has been carried out with 12 medium and large-sized manufacturing companies that have their headquarters in Italy. For each company the supply chain senior manager was interviewed. In 4 companies out of 12 , the supply chain managers work side-by-side with the logistics managers. Therefore these latter too were interviewed; ultimately 16 managers were interviewed. The sample of 12 companies was chosen based on the selection criteria given below:

1. must be medium or large-sized global enterprises. In this way they can better control the supply chain because of their contractual power, especially over small- to medium-sized enterprises;

2. must be very committed to the development of their supply chain and sharing knowledge linked to logistics improvements, such as lean and agile systems, specific software and electronic systems;

3. must measure supplier performance through similar indicators. Shared indicators include on-time delivery, products damaged and packaging compliance;

4. must be committed to the development of their supply chain from a sustainability and green point of view.

The companies have been suggested by two Italian consulting firms specialised in operations management. They have been doing consultancy in these companies for many years helping them to increase customer satisfaction and improve logistics processes. Table 1 below summarises the kinds of products these companies manufacture.

Tab. 1: The companies and their products

\begin{tabular}{|l|l|}
\hline Company & Product \\
\hline 1 & Filters for cars and lorries \\
\hline 2 & Air compressors \\
\hline 3 & Automatic machines for building industry \\
\hline 4 & Oil pumps \\
\hline 5 & Automotive components \\
\hline 6 & Electric engines \\
\hline 7 & Oil pumps \\
\hline 8 & Hot water eaters \\
\hline 9 & Diesel engines \\
\hline 10 & Process cranes \\
\hline 11 & Motorcycles \\
\hline 12 & Motorcycle components \\
\hline
\end{tabular}

Source: our research 
Because all the companies were based in Italy, it was also important that factors such as local laws and regulations should not influence the process of choosing logistics solutions.

The 12 companies represent a multi-case study and the research was carried out in an inductive and qualitative way by means of interviews (Orlikowski and Baroudi, 1991; Flyvbjerg, 2006).

Data collection was via semi-structured interviews. An interviewer guide was developed before interviewing the supply managers. For each company a supply manager was interviewed. In order to gather more data 4 other managers involved in logistics processes were interviewed too, for a total of 16 senior managers.

Table 2 shows the open questions used for the interview.

Tab. 2: Open questions used for the interview

\begin{tabular}{|c|c|c|}
\hline \multicolumn{3}{|c|}{$\begin{array}{c}\text { Interview focus: What are the best logistics solutions for improving customer } \\
\text { satisfaction? }\end{array}$} \\
\hline Id & Open questions & Notes \\
\hline 1 & $\begin{array}{l}\text { What are the warehouse and } \\
\text { inventory management solutions } \\
\text { implemented by your suppliers which } \\
\text { can affect your customer satisfaction? }\end{array}$ & $\begin{array}{l}\text { Discuss logistics solutions linked } \\
\text { just to physical products }\end{array}$ \\
\hline 2 & $\begin{array}{l}\text { What are the handling and packaging } \\
\text { solutions implemented by your } \\
\text { suppliers which can affect your } \\
\text { customer satisfaction? }\end{array}$ & $\begin{array}{l}\text { Discuss solutions related to } \\
\text { transportation, protection and } \\
\text { ease of handling products }\end{array}$ \\
\hline 3 & $\begin{array}{l}\text { Can the integration and control of the } \\
\text { supply chain of your suppliers in its } \\
\text { operations affect your satisfaction in } \\
\text { some ways? }\end{array}$ & $\begin{array}{l}\text { Investigate how the integration } \\
\text { can increase performances linked } \\
\text { to customer satisfaction }\end{array}$ \\
\hline 4 & $\begin{array}{l}\text { Does sharing and managing common } \\
\text { information technology processes } \\
\text { affect your satisfaction in some ways? }\end{array}$ & $\begin{array}{l}\text { Discuss only the information } \\
\text { technology } \\
\text { integration } \\
\text { concerning logistics data and } \\
\text { information }\end{array}$ \\
\hline 5 & $\begin{array}{l}\text { Does sharing and managing common } \\
\text { indicators and performance data } \\
\text { affect your satisfaction in some ways? }\end{array}$ & $\begin{array}{l}\text { Discussion only about sharing } \\
\text { indicators and data linked to } \\
\text { logistics performance }\end{array}$ \\
\hline 6 & $\begin{array}{l}\text { Does the mastery of logistics } \\
\text { knowledge and skills from your } \\
\text { suppliers affect your satisfaction in } \\
\text { some ways? }\end{array}$ & $\begin{array}{l}\text { Investigate about the logistics } \\
\text { knowledge and skills needed by } \\
\text { the customer from the supplier }\end{array}$ \\
\hline 7 & $\begin{array}{l}\text { What are the green logistics solutions } \\
\text { implemented by your suppliers which } \\
\text { can affect your customer satisfaction? }\end{array}$ & $\begin{array}{l}\text { Investigate about green initiatives } \\
\text { such as packaging recycling, less } \\
\text { polluting transportations, etc. }\end{array}$ \\
\hline 8 & $\begin{array}{l}\text { What are the reverse logistics solutions } \\
\text { implemented by your suppliers which } \\
\text { can affect your customer satisfaction? }\end{array}$ & $\begin{array}{l}\text { Investigate all the reverse } \\
\text { solutions during the life of the } \\
\text { product and also at the end-of-life } \\
\text { state }\end{array}$ \\
\hline
\end{tabular}

Source: our research 
sinergie Vol. 33, N. 97, 2015

The open questions are linked to the six key issues which emerged from the literature review. In particular the first and the sixth key issue have been brought into two open questions in order to better focus on complex issues such as inventory and warehouse management solutions and green logistics.

The interviews produced a lot of qualitative data. To facilitate analysis the NVivo ${ }^{\infty} 10$ software package was used and the data was coded and labelled in order to classify and assign meaning to parts of the information (Lofland and Lofland, 1995; Bazeley and Jackson, 2013).

At the end of the process, five theoretical categories were used to represent the logistics solutions which improved customer satisfaction according to the responses of the 16 senior managers. Table 3 in the following section summarises the coding results.

\section{Discussion}

As a first general result from the coding activity can be noticed (Table 3) that just five theoretical categories emerged from this inductive inquiry process. Comparing these categories with the eight key issues derived from the literature review a reduction in number can be observed. Table 3 presents the five theoretical categories in the last column, while in the central column named Initial coding, can be found the single logistics solutions within the five categories. In fact, in the central column only the codes, or logistics solutions, proposed by the respondents that have more than nine concordant respondents have been taken into account. For each theoretical category, the average of the number of concordant respondents to the solutions has been calculated. These average values have been displayed in the radar-chart of Figure 1, showing that 'Supplier with Innovative logistics knowledge and skills' is considered the most important category which affects customer satisfaction (average 15.5); on the other hand, 'Sharing ICT and logistics performance measurement system, with an average value of 9 , is considered the least important for customer satisfaction. 
Tab. 3: Coding and grouping qualitative data from the interviews

\begin{tabular}{|c|c|c|c|}
\hline Responses & Initial coding & $\begin{array}{l}\text { Concordant } \\
\text { respondents }(\geq 9)\end{array}$ & $\begin{array}{l}\text { Focused coding } \\
\text { (theoretical } \\
\text { categories) }\end{array}$ \\
\hline \multirow[t]{18}{*}{$\begin{array}{l}\text { Data from the } 12 \\
\text { interviews }\end{array}$} & $\begin{array}{l}\begin{array}{l}\text { Using } \\
\text { solutions }\end{array} \\
\end{array}$ & $15 / 16$ & \multirow[t]{4}{*}{$\begin{array}{l}\text { Agile and leanness } \\
\text { solutions }\end{array}$} \\
\hline & Using agile solutions & $15 / 16$ & \\
\hline & $\begin{array}{l}\text { Using packaging } \\
\text { easier to handle and } \\
\text { storage }\end{array}$ & $15 / 16$ & \\
\hline & $\begin{array}{l}\text { Using agile reverse } \\
\text { logistics in case of } \\
\text { defective products }\end{array}$ & $14 / 16$ & \\
\hline & & Average 14.75 & \multirow{4}{*}{$\begin{array}{l}\text { Sharing ICT and } \\
\text { logistics performance } \\
\text { measurement system }\end{array}$} \\
\hline & $\begin{array}{l}\text { Using the same } \\
\text { logistics ICT } \\
\text { solutions from the } \\
\text { customer to the } \\
\text { supplier and its sub- } \\
\text { suppliers }\end{array}$ & $9 / 16$ & \\
\hline & $\begin{array}{l}\text { Sharing at least KPIs } \\
\text { such as on-time } \\
\text { delivery, percentage } \\
\text { of compliant } \\
\text { packaging }\end{array}$ & $9 / 16$ & \\
\hline & & Average 9 & \\
\hline & $\begin{array}{l}\text { Supplier able to } \\
\text { design } \quad \text { logistics } \\
\text { solutions involving its } \\
\text { sub-suppliers } \\
\end{array}$ & $15 / 16$ & \multirow[t]{2}{*}{$\begin{array}{lr}\text { Supplier } & \text { with } \\
\text { innovative } & \text { logistics } \\
\text { knowledge and skills }\end{array}$} \\
\hline & $\begin{array}{l}\text { Supplier } \quad \text { with } \\
\text { innovative logistics } \\
\text { knowledge and skills }\end{array}$ & $16 / 16$ & \\
\hline & & Average 15.5 & \multirow{4}{*}{$\begin{array}{l}\text { Green } \\
\text { solutions }\end{array}$} \\
\hline & $\begin{array}{l}\text { Packaging in } \\
\text { compliance with all } \\
\text { laws and regulations }\end{array}$ & $14 / 16$ & \\
\hline & $\begin{array}{l}\text { Recycling } \\
\text { packaging }\end{array}$ & $13 / 16$ & \\
\hline & $\begin{array}{l}\text { Reuse of boxes and } \\
\text { containers }\end{array}$ & $15 / 16$ & \\
\hline & & Average 14 & \multirow{4}{*}{$\begin{array}{l}\text { Reverse } \\
\text { solutions }\end{array}$} \\
\hline & $\begin{array}{lr}\text { Managing } & \text { reverse } \\
\text { logistics } & \text { for } \\
\text { e n viron m e n t a l } \\
\text { problems }\end{array}$ & $10 / 16$ & \\
\hline & $\begin{array}{l}\text { Managing reverse } \\
\text { logistics at the } \\
\text { product's end-of-life }\end{array}$ & $9 / 16$ & \\
\hline & & Average 9.5 & \\
\hline
\end{tabular}

Andrea Chiarini Alex Douglas

The impact of logistics

solutions on customer

satisfaction: an

exploratory qualitative

study of manufacturing

companies

Source: our research 


\section{sinergie} Vol. 33, N. 97, 2015
Fig. 1: The importance of the five theoretical categories

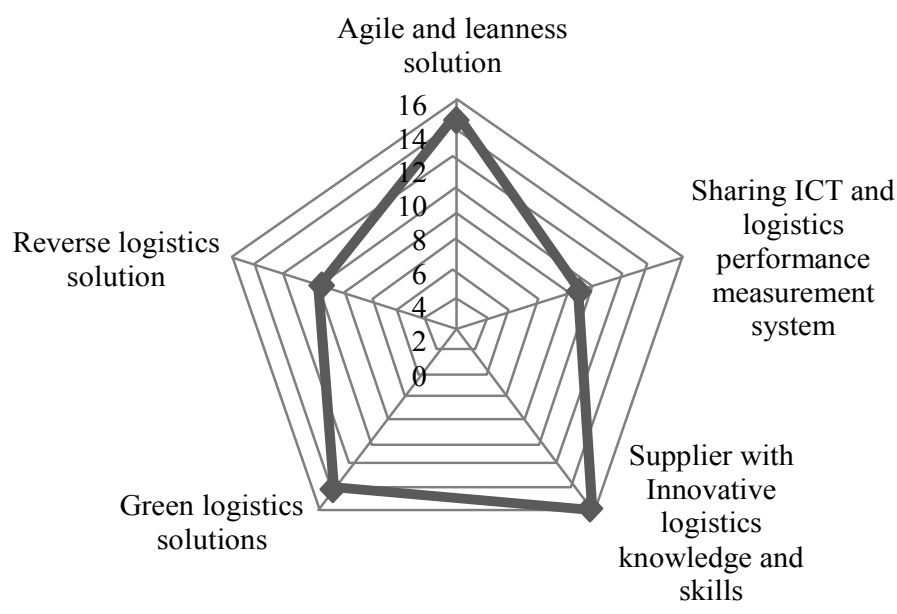

Source: our research

In the following five sub-sections the paper analyses and discusses further details about these logistics solutions with in-depth analyses of the managers' responses and comments.

\section{Agile and leanness solutions}

According to all interviewed supplier and logistics managers, in order to increase customer satisfaction their suppliers have to embrace some lean and agile solutions. All the respondents underlined how the focus is to increase on-time delivery performance and at the same time reduce the delivery time. To achieve these performance improvements the supplier has to embrace lean and agile solutions. Some respondents stated that in the past their suppliers met their on-time delivery goals by means of high levels of inventory. Products were always available in high quantities but unfortunately this way of managing the warehouse is not economically viable in the long term for suppliers who, sooner or later, as a consequence of higher inventory costs, start increasing the cost of their products. To avoid this, suppliers have to implement Just-In-Time solutions such as Kanban ${ }^{3}$ or consignment stock ${ }^{4}$. Interestingly, different managers with similar words stated: you cannot increase the level of service for your customer just by using high inventory. The more inventory, the more the problems in your operations.

Out of the 16 respondents, 15 believed that lean solutions are fundamental. Indeed, customer satisfaction derives from having always the right amount of products at the right time with reduced costs.

3 Kanban is a Japanese term meaning card. Cards can be seen within the container of products when it is emptied, allowing the production and delivery of new products before a shortage to the customer develops.

4 With the consignment stock, products are in possession of the customer that is not the products' owner; this usually is the supplier. The supplier manages and provides the products at the customer's warehouse. 
Out of the 16 respondents, 15 also believed that their suppliers had to develop new agile solutions in order to reduce transportation and delivery times. Agile solutions such as fast opening and closing as well as easy transportation were very important for all 16 respondents. For instance, one manager declared that transportation design is usually managed by the supplier and you cannot do anything to improve it. Moreover, the packaging had to be in compliance with dimensions and characteristics designed by the customer increasing in this way its standardisation. According to almost all the respondents, standardisation is one of the most important solutions for reducing costs of transportation, handling and storage. Furthermore, 14 out of 16 respondents believed that agile solutions had to be applied in case of defects or order discrepancies when products had to be returned to their suppliers. According to the 14 respondents, this process was fundamental and the supplier had to implement logistics solutions such as fast track air freight and specific cargo services. According to the respondents, their suppliers also had to hold in their warehouses safety stock dedicated to the replacement of defective products.

\section{Sharing ICT and logistics performance measurement system}

Something less tangible, such as the ICT system, can increase customer satisfaction; however, based on respondents' answers, it seems less important than other categories. In fact, just nine respondents out of 16 believed that using the same logistics ICT solutions from the customer to the supplier and its sub-suppliers would be of any help. These nine respondents suggest that the supplier should implement ICT solutions such as the same inventory management software, the same electronic picking systems, the same barcodes and electronic shipment notifications.

Among the respondents, there were also seven opponents to sharing ICT logistics solutions. According to these managers, a supplier could implement a different ICT system for each customer. This would fall on the cost of product because the supplier could not manage such a complex logistics organisation.

A manager, for instance, explained how they had implemented a very expensive Enterprise Resource Planning (ERP) software and the suppliers, especially the small-sized ones, could not afford such investment. Out of the 16 respondents, nine were of the opinion that customers and suppliers should at least share logistics KPIs. Although the nine respondents propose different KPIs, they agree with each other that the most basic and fundamental KPIs should be on-time delivery and percentage or number of packaging complaints (e.g. damaged, badly packed and sealed, contaminated, not in compliance with laws and regulations).

\section{Supplier with innovative logistics knowledge and skills}

Another non-tangible asset that the supplier has to have to increase customer satisfaction is good logistics knowledge as well as logistics skills. 15 respondents out of 16 believed that the supplier had to be able to design new logistics networks required when markets changed. One of the respondents for instance gave an example of a supplier who was able to implement from scratch a logistics network for supplying a new Chinese 
sinergie Vol. 33, N. 97, 2015

plant. Another respondent gave an example of co-designing with the supplier of a particular packaging and transportation solutions against saltiness in some docks.

According to all 16 respondents, the ability of designing logistics solutions was strictly linked to the supplier skills acquired over time.

\section{Green logistics solutions}

Customer satisfaction is also linked to green logistics solutions related to packaging and transportation. First of all, according to 14 respondents, the packaging had to be in compliance with all the environmental laws and regulations. This was taken for granted. According to all the respondents, the packaging had to refer to all data and information due by law such as the CLP Regulation (European Union, 2008). If the packaging did not contain such data the company could be fined by the authorities and this could even jeopardise the business.

By the same token, packaging and boxes used for carrying the products had to be recyclable and reusable. In particular, according to 15 respondents, boxes had to be reused several times between the customer and its supply chain thus avoiding the cost of buying new boxes.

Unusually just six respondents out of 16 pointed out their attention to green logistics solutions linked to transportations. Therefore, according to the criteria of also taking into account theoretical categories stated by more than eight respondents (from 9 to 16) it has been considered not that relevant. These six respondents suggested that for their satisfaction it was important to choose greener couriers and green transportation modes. However, according to these respondents, there could be a tradeoff between green couriers, cost of transportation and the quality of transportation service. Indeed, it was not expected that the best courier in service was also the greenest or the cheapest. According to some interviewed managers the current economic crisis has brought into question expenditures related to green solutions for transportations.

\section{Reverse logistics solutions}

According to the literature review reverse logistics could be divided into different processes. One of them was fundamental to giving good service to the customer when the product was defective or there were order discrepancies. Another relevant process within the so-called reverse logistics was linked to the end-of-life of the product. Customers, at this particular final stage, often had to throw out the product transferring it from the point of use and disposal to the point of treatment. According to 9 of the 16 respondents, if the supplier could entirely manage this process, including all the logistics activities, it was a significant advantage for the customer. However not all respondents agreed with these particular solutions: two respondents were uncertain, while six considered the solution entirely managed by the supplier too expensive and they preferred to dispose of the product waste themselves. Once more, according to the six respondents, the current economic crisis has slowed down the implementation of processes such as reverse logistics for the end-of-life. 
Sadly, one manager stated: in 2013 our turnover plummeted by 20\%, who cared about product end-of-life? We just did not sell any new product.

Finally, for ten respondents it was important that the supplier was able to manage the return of products in case of environmental problems such as wrong environmental labelling or leaks, oxidations, contaminations, and so on.

\section{Conclusions}

This research study began with a literature review where eight key issues about customer satisfaction and logistics solutions were identified. These key issues were used to design a semi-structured interview questionnaire. Some managers were asked to give their views on the kinds of logistics solutions their suppliers would have to implement to increase their customer satisfaction.

Based on the number of respondents, agreeing with the particular logistics solutions, five theoretical categories were ranked in order of importance. In this way the category 'Supplier with innovative logistics knowledge and skills' was surprisingly identified as the most important category for increasing customer satisfaction. In this category customers required that their suppliers should have the ability of designing new logistics networks and solutions particularly when markets change. Ranked second was 'Green logistics solutions' which refers to the compliance of the packaging with laws and regulations as well as reuse and recycling of the product. Ranked third was bound to lean and agile solutions. According to the literature review this is the most expected result. Indeed, solutions linked to on-time delivery and quickness of delivery were especially taken for granted by customers.

Last but not least, two theoretical categories came in the last positions in terms of interest; these were 'Reverse logistics solutions' and 'Sharing ICT and logistics performance measurement system'. Reverse logistics solutions were solely related to environmental problems of products and the special stage of the end-of-life of the product. Unexpectedly, the sharing of ICT solutions and performance measurements was deemed to be not as important as the other categories. This view seems due to the fact that the senior managers interviewed were conscious that sharing a different ICT system for each customer could be unaffordable for their suppliers. Moreover, the lack of interest about reverse logistics solutions from an environmental standpoint as well as other issues related to the product end-of-life management seem linked to the current economic crisis and deserve to be better investigated.

This research has several limitations which lead to avenues for new research. First of all the qualitative inductive inquiry was based on a small sample of 12 manufacturing companies and 16 interviewees. In this sense it could be considered an exploratory research study. Future research could use a larger sample to facilitate a more quantitative study associated with a survey and statistical analyses and tests. The five theoretical categories could become hypotheses to be tested. Furthermore, the research scope could be broadened to different kinds of industries and to companies which belong to different geographical areas.
Andrea Chiarini Alex Douglas The impact of logistics solutions on customer satisfaction: an exploratory qualitative study of manufacturing companies 
Sinergie Vol. 33, N. 97, 2015
This research has also brought to light some interesting practical implications. Practitioners who want to implement logistics solutions in manufacturing companies using the results of this research will be aware of the priorities to pursue in terms of customer satisfaction.

\section{References}

BAZELEY P., JACKSON K. (2013), Qualitative data analysis with NVivo, Sage Publications Limited, London.

BEAMON B.M. (1999), "Measuring supply chain performance", International Journal of Operations and Production Management, vol. 19, n. 3, pp. 275292.

BIENSTOCK C.C., ROYNE M.B., SHERRELL D., STAFFORD T.F. (2008), “An expanded model of logistics service quality: Incorporating logistics information technology", International Journal of Production Economics, vol. 113, n. 1, pp. 205-222.

BOWERSOX D.J., CLOSS D.J., COOPER M.B. (2002), Supply chain logistics management (vol. 2), McGraw-Hill, New York.

CERMAK D.S., FILE K.M., PRINCE R.A. (2011), "Customer participation in service specification and delivery", Journal of Applied Business Research, vol. 10, n. 2, pp. 90-97.

CHIARINI A. (2014), "Strategies for developing an environmentally sustainable supply chain: differences between manufacturing and service sectors", Business Strategy and the Environment, vol. 23, n. 7, pp. 493-504.

CHOI T.Y., EBOCH K. (1998), “The TQM paradox: relations among TQM practices, plant performance, and customer satisfaction", Journal of Operations Management, vol. 17, n. 1, pp. 59-75.

DEKKER R., BLOEMHOF J., MALLIDIS I. (2012), "Operations Research for green logistics-An overview of aspects, issues, contributions and challenges", European Journal of Operational Research, vol. 219, n. 3, pp. 671-679.

DEL BALDO M. (2011), "Logistica: punto di incontro o di scontro tra old e new economy?", Sinergie, n. 57, pp. 87-105.

EUROPEAN UNION REGULATION (2008), Regulation n. 1272/2008. Regulation on classification, labelling and packaging of substances and mixtures, amending and repealing Directives 67/548/EEC and 1999/45/EC, and amending Regulation (EC) n. 1907/2006.

FLEISCHMANN M., KRIKKE H.R., DEKKER R., FLAPPER S.D.P. (2000), “A characterisation of logistics networks for product recovery", Omega, vol. 28, n. 6, pp. 653-666.

FLINT D.J., BLOCKER C.P., BOUTIN JR P.J. (2011), "Customer value anticipation, customer satisfaction and loyalty: An empirical examination", Industrial Marketing Management, vol. 40, n. 2, pp. 219-230.

FLYVBJERG B. (2006), "Five Misunderstandings About Case-Study Research", Qualitative Inquiry, vol. 12, n. 2, pp. 219-245.

GENCHEV S.E., RICHEY R.G., GABLER C.B. (2011), "Evaluating reverse logistics programs: a suggested process formalization", The International Journal of Logistics Management, vol. 22, n. 2, pp. 242-263. 
GRIFFIN A., GLEASON G., PREISS R., SHEVENAUGH D. (1995), “Best practice for customer satisfaction in manufacturing firms", Sloan Management Review, vol. 36, n. 2, available at: http://sloanreview.mit.edu/article/best-practicefor-customer-satisfaction-in-manufacturing-firms/

GUNASEKARAN A., PATEL C., TIRTIROGLU E. (2001), "Performance measures and metrics in a supply chain environment", International journal of operations and production Management, vol. 21, n. 1/2, pp. 71-87.

GUNASEKARAN A., PATEL C., MCGAUGHEY R.E. (2004), "A framework for supply chain performance measurement", International journal of production economics, vol. 87, n. 3, pp. 333-347.

KHAN M.S., NAUMANN E., WILLIAMS P. (2012), "Identifying the key drivers of customer satisfaction and repurchase intentions: An empirical investigation of Japanese B2B services", Journal of Consumer Satisfaction, Dissatisfaction and Complaining Behavior, vol. 25, n. 3, pp. 159-178.

KHURANA H., SOHAL J.S. (2011), "Implementation of New Management Agile Technique for Reducing Overtime and Increasing Customer Satisfaction Hossain", International Journal of Engineering Science and Technology, vol. 3, n. 1. pp. 238-241.

KRISTIANTO Y., AJMAL M.M., SANDHU M. (2012), "Adopting TQM approach to achieve customer satisfaction: A flour milling company case study", The TQM Journal, vol. 24, n. 1, pp. 29-46.

LAI K.H., CHENG T.E. (2009), Just-in-time logistics, Gower Publishing, Ltd, Burlington.

LOFLAND J., LOFLAND L.H. (1995), Analyzing Social Settings: A Guide to Qualitative Observation and Analysis, Wadsworth, Belmont CA.

LUN Y.V., LAI K.H., CHENG T.C.E., SHANG K.C. (2015), "Examining the influence of organizational capability in innovative business operations and the mediation of profitability on customer satisfaction", International Journal of Production Economics, Article in press.

MCKINNON A., BROWNE M., WHITEING A. (2012), Green logistics: Improving the environmental sustainability of logistics, Kogan Page Publishers, New York.

MEYBODI M.Z. (2015), “The links between just-in-time practices and alignment of benchmarking performance measures", The TQM Journal, vol. 27, n. 1 (Article in press).

MURPHY P.R., POIST R.F., BRAUNSCHWEIG C.D. (1996), "Green logisticscomparative views of environmental progressives, moderates and conservatives", Journal of Business Logistics, vol. 17, n. 1, pp. 191-211.

MURPHY P.R., POIST R.F. (2000), "Green logistics strategies: an analysis of usage patterns", Transportation Journal, vol. 40, n. 2, pp. 5-16.

ORLIKOWSKI W., BAROUDI J.J. (1991), "Studying information technology in organisations: research approaches and Assumptions", Information Systems Research, vol. 2, pp. 1-28.

ROGERS D.S., TIBBEN-LEMBKE R. (2001), "An examination of reverse logistics practices", Journal of Business Logistics, vol. 22, n. 2, pp. 129-148.

SBIHI A., EGLESE R.W. (2007), "Combinatorial optimization and green logistics", 4OR, vol. 5, n. 2, pp. 99-116.

SBIHI A., EGLESE R.W. (2010), "Combinatorial optimization and green logistics", Annals of Operations Research, vol. 175, n. 1, pp. 159-175. 
sinergie Vol. 33, N. 97, 2015

SHARMA A., GREWAL D., LEVY M. (1995), “The customer satisfaction/logistics interface", Journal of Business Logistics, vol. 16, n. 1, pp. 14-21.

STANK T.P., GOLDSBY T.J., VICKERY S.K., SAVITSKIE K. (2003), "Logistics service performance: estimating its influence on market share", Journal of Business Logistics, vol. 24, n. 1, pp. 27-55.

TRACEY M., LENG TAN C. (2001), "Empirical analysis of supplier selection and involvement, customer satisfaction, and firm performance", Supply Chain Management: An International Journal, vol. 6, n. 4, pp. 174-188.

VONA R. (2011), "Riflessioni sul concetto di distretto logistico", Sinergie, n. 56, pp. 229-250.

ZHANG Q., VONDEREMBSE M.A., LIM J.S. (2005), "Logistics flexibility and its impact on customer satisfaction", The International Journal of Logistics Management, vol. 16, n. 1, pp. 71-95.

\section{Academic or professional position and contacts}

Andrea Chiarini

Adjunt Professor of Logistics and Operations Management

University of Ferrara - Italy

e-mail: andrea.chiarini@unife.it

\section{Alex Douglas}

Editor-In-Chief, The TQM Journal - Emerald

Professor in Quality Management at The Management University of Africa, Nairobi, Kenya e-mail: tqmeditor@gmail.com

sinergie

italian journal of management

ISSN 0393-5108 DOI 10.7433/s97.2015.16 pp. $255-270$

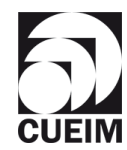

